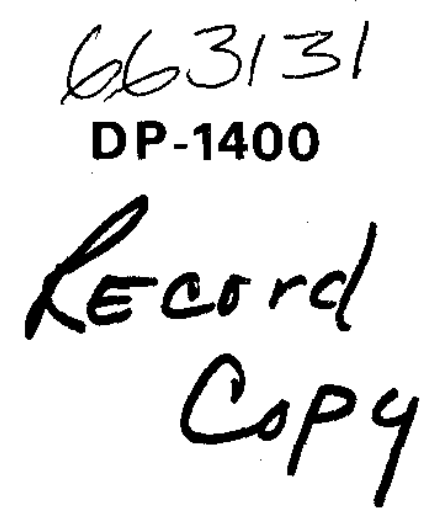

\title{
AN IMPACT TEST FOR SOLID WASTE FORMS
}

R. M. WALLACE

1

J. A. KELLEY

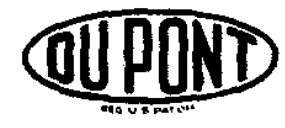

SAVANNAH RIVER LABORATORY AIKEN, SOUTH CAROLINA 29801 


\section{INTERNAL DISTRIBUTION}

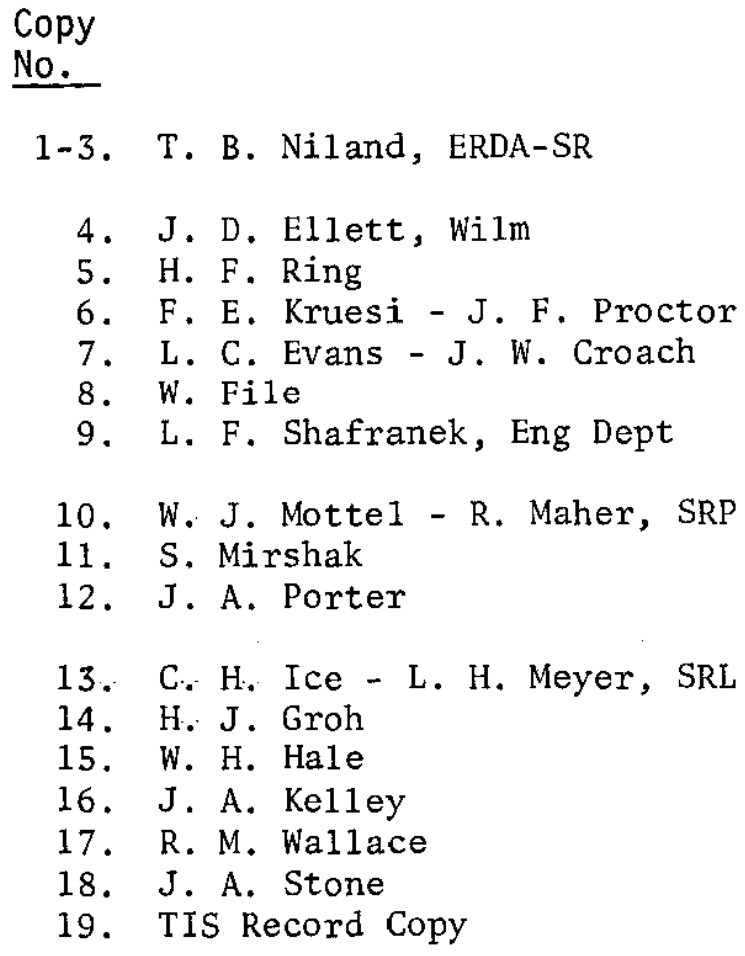


DP -1400

Distribution Category: UC-38

\section{AN IMPACT TEST FOR SOLID WASTE FORMS}

by

R. M. Wallace and J. A. Kelley

Approved by

W. H. Hale, Jr., Research Manager

Separations Chemistry Division

Publication Date: March 1976

E. I. DU PONT DE NEMOURS AND COMPANY

SAVANNAH RIVER LABORATORY

AIKEN, SOUTH CAROLINA 29801

PREPARED FOR THE U.S. ENERGY RESEARCH AND DEVELOPMENT ADMINISTRATION UNDER CONTRACT AT (07-2)-I 


\section{ABSTRACT}

Samples of concretes and glasses being considered for incorporation of radioactive waste sludge were subjected to impact tests to determine the relationship between the energy of the impact and the resulting increase in surface area of the damaged sample. Test results indicate that the increased surface area per unit of energy input for glass waste forms is less by a factor of about three than that for concretes containing $40 \mathrm{wt} \%$ simulated sludge (average values of $9.6 \mathrm{~cm}^{2} / J$ oule and $24.7 \mathrm{~cm}^{2} /$ Joule for glass and concrete, respectively). 


\section{CONTENTS}

Introduction 5

Experimenta1 5

Results 9

Conclusions 16

Acknow ledgment $\quad 16$

References $\quad 16$ 


\section{LIST OF TABLES}

1 Composition of Glass Used in Impact Tests 8

2 Composition of Concretes Used in Impact Tests 8

3 Particle Size Distribution of Glass

Crushed by Impact 10

4 Particle Size Distribution of Concretes

Crushed by Impact 11

5 Surface Area Created When Waste Forms

Were Crushed by Impact 15

\section{LIST OF FIGURES}

1 Schematic Diagram of Impact Test Apparatus 6

2 Particle Size Distribution of Glass Crushed by Impact 10

3 Particle Size Distribution of High Alumina Concrete Crushed by Impact 12

4 Particle Size Distribution of Type I-P Concrete Crushed by Impact 13

5 Particle Size Distribution of Type III Concrete Crushed by Impact 14 


\title{
AN IMPACT TEST FOR SOLID WASTE FORMS
}

\author{
INTRODUCTION
}

Compressive strength tests are commonly used in the evaluation of solid forms for nuclear wastes, however, a connection between strengths and the safety of waste forms has not been established. These tests measure the stress required to fracture or permanently deform a material, but any material, if subjected to a sufficiently large stress (such as one caused by an explosion or airplane crash in a waste storage facility), will fracture or deform. Compressive strength alone, then, does not give a good measure of the safety of waste forms when subjected to impact. A test is therefore required that measures a property of waste forms that is changed by impact and is likely to affect directly the safety of the waste storage system.

The physical characteristic of a waste form that is most likely to change under impact and subsequently affect the safety of the system is the particle size distribution. Formation of a large number of small particles from a monolith will increase surface area and thus its potential for water-leaching should the particulate waste escape from its container and become exposed to water or air. In addition, the very small particles are apt to become dispersed by wind and create an airborne hazard.

This report describes preliminary results in the development of a test in which samples are broken by impact of known energy and the particle size distribution of the sample is determined after impact. The increased surface areas are then estimated from the particle size distributions and assumptions concerning the shape of the particles.

\section{EXPERIMENTAL}

Figure 1 is a diagram of the impact test apparatus. It consists of a hardened tool steel mortar, a cylindrical pestle of the same material machined to fit (slip fit) in a cavity within the mortar, a two-kilogram steel weight, and a guide tube for the weight. 


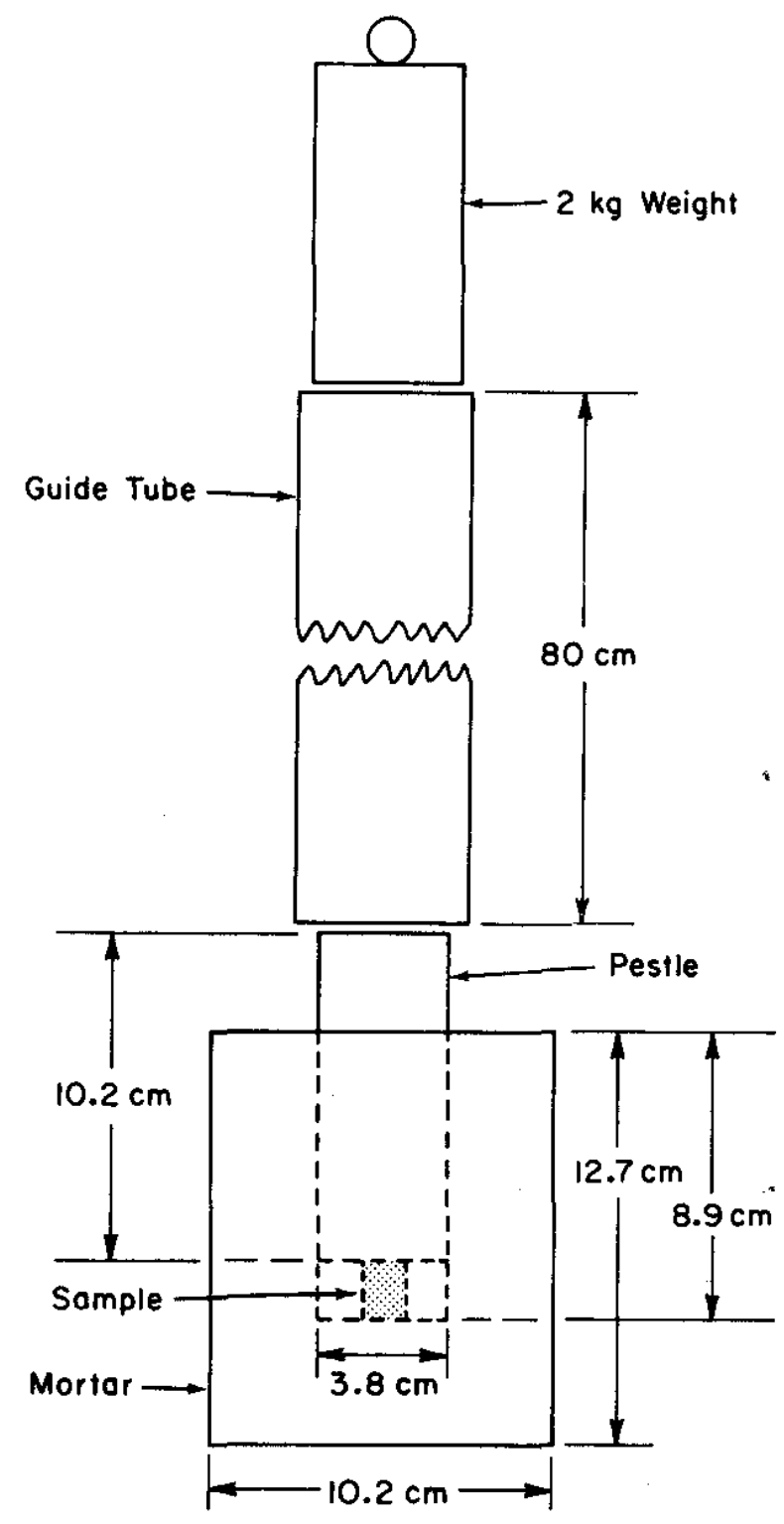

FIGURE 1. Schematic Diagram of Impact Test Apparatus 
In operation, a weighed cylindrical sample of the material to be tested was placed in the cavity within the mortar, and the pestle was placed firmly upon it. The two kilogram weight was then dropped from a known height, through the guide tube to strike the pestle near the center. The weight was dropped as often as necessary to obtain the desired energy input. The guide tube in the present apparatus was only 80 centimeters long, so that a maximum of $1.6 \mathrm{kilogram}$-meters (kg-m) (15.7 Joules) of energy could be applied at one blow. The weight could be dropped a shorter distance by pulling it up to the desired height by a cord attached to a ring on top.

After the sample was crushed, it was transferred to a stack of $7.6-\mathrm{cm}$-diameter standard sieves and screened by agitating the stack for five minutes on a Cenco-Meinzer sieve shaker that had been modified to accommodate the small sieves. The sieves in the stack were those with U.S. Standard sieve numbers $10,18,35,60$, and 120 , which correspond to sieve openings of $2000,1000,500$, 250 , and 125 microns, respectively. With certain samples, material passing through sieve number 120 was further analyzed by screening through additional sieves, and the material that passed through sieve number 325 was analyzed with a Coulter Counter (Coulter Electronics Co.).

Impact tests were made on one glass formulation and five formulations of concrete. The preparation of the glass was described in detail by Kelley; ${ }^{1}$ its composition is shown in Table 1. The glass was cast in graphite molds to produce cylindrical specimens $1.3 \mathrm{~cm}$ in diameter. After specimens were annealed and cooled, they were cut to $2.5-\mathrm{cm}$ lengths having parallel faces. The preparation of concrete formulations was discussed by Stone, and their compositions are shown in Table 2 . The ingredients were mixed, cast in $2.5-\mathrm{cm}$-diameter plastic tubes, and allowed to cure at room temperature and $100 \%$ relative humidity for at least 28 days. Specimens were cut to $1.3-\mathrm{cm}$ lengths for the impact test.

The glass sample was crushed initially by application of an energy of $2 \mathrm{~kg}-\mathrm{m}$ and then screened through the stack of sieves, the smallest of which was 125 microns. The crushed sample was returned to the mortar, crushed again with another $2 \mathrm{~kg}-\mathrm{m}$ of energy and screened in the same manner. This procedure was continued until a total of $8 \mathrm{~kg}-\mathrm{m}$ of energy had been employed, after which a complete particle size analysis was performed.

Concrete samples were crushed with $4.8 \mathrm{~kg}-\mathrm{m}$ of energy and screened as described for the initial glass sample. The samples were then returned to the mortar, crushed again with another $4.8 \mathrm{~kg}$ - $\mathrm{m}$, and finally subjected to the more complete particle size analysis. 


\section{TABLE $]$}

Composition of Glass Used in Impact Tests

Composition of Glass Mix Components

Component Wt \%

$\mathrm{SiO}_{2}$

52.5

$\mathrm{B}_{2} \mathrm{O}_{3}$

10.0

$\mathrm{Na}_{2} \mathrm{O}$

22.5

$\mathrm{TiO}_{2}$

10.0

$\mathrm{CaO}$

5.0

Composition of Glass Waste Form

G1ass Mix

sludge $e^{a}$

45.0

a. Sludge contained 50 mole $\% \mathrm{Fe}(\mathrm{OH})_{3}$ and 50 mole $\% \mathrm{MnO}_{2}$.

TABLE 2

Composition of Concretes Used in Impact Tests

Weight Ratios
Water to Sludge
Cement to
Sludge + Cement

$\begin{array}{lll}\text { Port land-I-P } & 0.335 & 0.0 \\ \text { High Alumina } & 0.273 & 0.0 \\ \text { High Alumina } & 0.620 & 0.40 \\ \text { Port land-III } & 0.840 & 0.40 \\ \text { Port land-I-P } & 0.770 & 0.40\end{array}$

a. The sludge used in all specimens was 50 mole $\%$ $\mathrm{Al}(\mathrm{OH})_{3}$ and 50 mole $\% \mathrm{Fe}(\mathrm{OH})_{3}$. 


\section{RESULTS}

The particle size distributions of a sample of glass crushed by application of different amounts of energy are shown in Table 3 and Figure 2. Similar data for the concrete samples are shown in Table 4 and Figures 3 through 5 . The tables give the cumulative percentage (by weight) of material of particle size less than a given value. Log-log plots of these data are given in the figures.

The surface areas of the crushed samples were estimated as follows: the particles were assumed to be perfect spheres with diameter, $\bar{x}_{i}$, equal to the average particle size within a given size fraction, $i$. The ratio of area $A_{i}$, to volume $V_{i}$, within that fraction is given by

$$
\frac{A_{i}}{V_{i}}=\frac{6}{\bar{x}_{i}}
$$

The volume of material within that fraction can be written in terms of its mass, $g_{i}$, and its density, $\rho$.

$$
V_{i}=\frac{g_{i}}{\rho}
$$

The mass of the $i^{\text {th }}$ fraction can be written in terms of the total mass of the sample, $g_{t}$, and the fraction, $f_{i}$, of the material within it

$$
g_{i}=f_{i} g_{t}
$$

Combining equations (1), (2), and (3)

$$
A_{i}=\frac{6 g_{t}}{\rho} \cdot \frac{f_{i}}{\bar{x}_{i}}
$$

The total area, A, is the sum of the areas of the various fractions

$$
\begin{aligned}
& A=\sum_{i} A_{i} \\
& A=\frac{6 g_{t}}{\rho} \cdot \sum \frac{f_{i}}{\bar{x}_{i}}
\end{aligned}
$$


TABLE 3

Particle Size Distribution of Glass Crushed by Impact

\begin{tabular}{rcccc} 
Particle size & \multicolumn{5}{c}{ Cumulative \% with Particle Size Less Than $x$} \\
\cline { 2 - 5 }$(x)$, microns & $2 \mathrm{~kg}-\mathrm{m}$ & $4 \mathrm{~kg}-\mathrm{m}$ & $6 \mathrm{~kg}-\mathrm{m}$ & $8 \mathrm{~kg}-\mathrm{m}$ \\
2000 & 26.4 & 51.2 & 70.3 & 81.9 \\
1000 & 14.2 & 33.4 & 47.8 & 57.4 \\
500 & 7.4 & 19.5 & 31.1 & 38.6 \\
250 & 3.7 & 10.8 & 18.9 & 23.4 \\
125 & 1.7 & 5.3 & 9.9 & 12.1 \\
62 & - & - & - & 6.2 \\
33 & - & - & - & 1.24 \\
16 & - & - & - & 0.11 \\
8 & - & - & - & 0.0
\end{tabular}

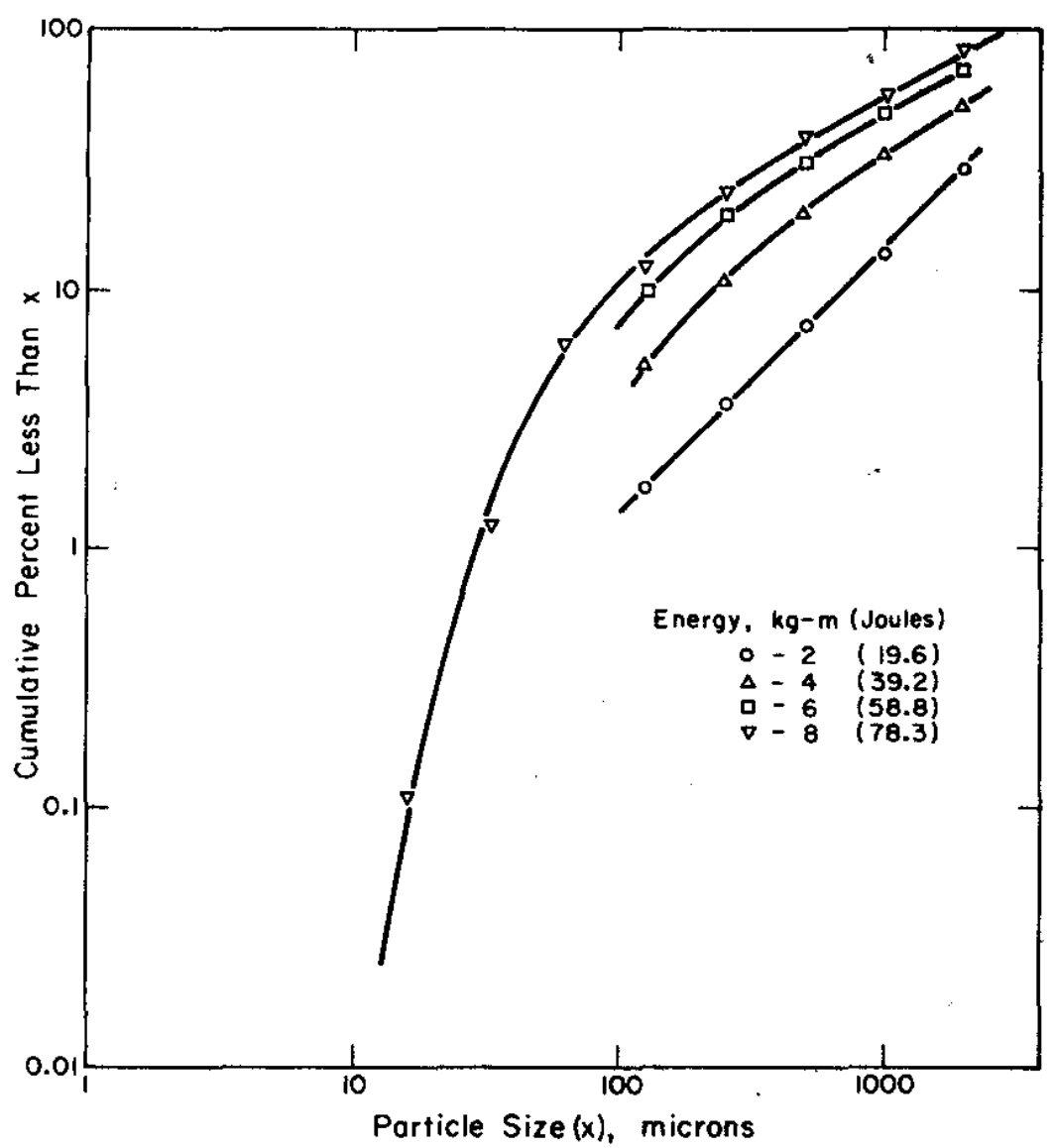

FIGURE 2. Particle Size Distribution of Glass Crushed by Impact 
TABLE 4

Particle Size Distribution of Concretes Crushed by Impact

\begin{tabular}{|c|c|c|c|c|c|c|c|c|c|c|c|c|}
\hline \multirow{2}{*}{$\begin{array}{l}\text { Size (x), } \\
\text { sicrons } \\
2000\end{array}$} & \multicolumn{2}{|c|}{ 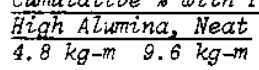 } & \multicolumn{2}{|c|}{ 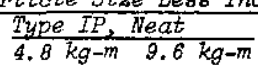 } & \multicolumn{2}{|c|}{ 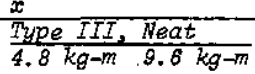 } & \multicolumn{2}{|c|}{ 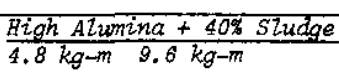 } & \multicolumn{2}{|c|}{$\begin{array}{l}\text { Type IP + } 40 \% \text { Studge } \\
4.8 \mathrm{~kg}-\mathrm{m} \\
9.6 \mathrm{~kg}-\mathrm{m}\end{array}$} & \multicolumn{2}{|c|}{$\frac{\text { Type III }+40 \% \text { Siudge }}{4.8 \mathrm{~kg}-\mathrm{m}} 9.6 \mathrm{~kg}-\mathrm{m}$} \\
\hline & 20.9 & 49.6 & 38.1 & 58.0 & 34.1 & 63.6 & 49.3 & 70.6 & 54.1 & 76.5 & 50.6 & 63.4 \\
\hline 1000 & 9.3 & 27.2 & 17.4 & 32.5 & 14.4 & 36.5 & 29.8 & 50.8 & 30.8 & 53.2 & 30.5 & 43.1 \\
\hline 500 & 4.9 & 16.1 & 8.7 & 17.6 & 6.4 & 19.5 & 19.3 & 36.0 & 16.7 & 33.7 & 20.2 & 29.5 \\
\hline 250 & 2.8 & 9.8 & 4.3 & 9.7 & 3.4 & 10.5 & 12.9 & 25.0 & 9.4 & 19.8 & 13.1 & 20.3 \\
\hline 125 & 1.4 & 4.2 & 2.3 & 5.5 & 2.0 & 5.5 & 4.5 & 16.1 & 5.0 & 10.8 & 8.3 & 12.5 \\
\hline 62 & - & 2.1 & - & 2.8 & - & - & - & 10.3 & - & 6.2 & - & 8.8 \\
\hline 33 & - & 0.71 & - & 1.27 & - & - & - & 4.7 & - & 2.7 & - & 5.5 \\
\hline 16 & - & 0.21 & - & 0.48 & - & - & - & 2.2 & - & 1.03 & - & 2.4 \\
\hline 8 & - & 0.057 & - & 0.15 & - & - & - & 0.90 & - & 0.38 & - & 0.63 \\
\hline 4 & - & 0.034 & - & 0.072 & - & - & - : & 0.40 & - & 0.21 & - & 0.20 \\
\hline 2 & - & 0.016 & - & 0.032 & - & - & - & 0.16 & - & 0.11 & - & 0.084 \\
\hline 1 & - & 0.0 & - & 0.0 & - & - & - & 0.03 & - & 0.03 & - & 0.014 \\
\hline 0.6 & - & 0.0 & - & 0.0 & - & - & :- & 0.0 & - & 0.0 & - & 0.0 \\
\hline
\end{tabular}




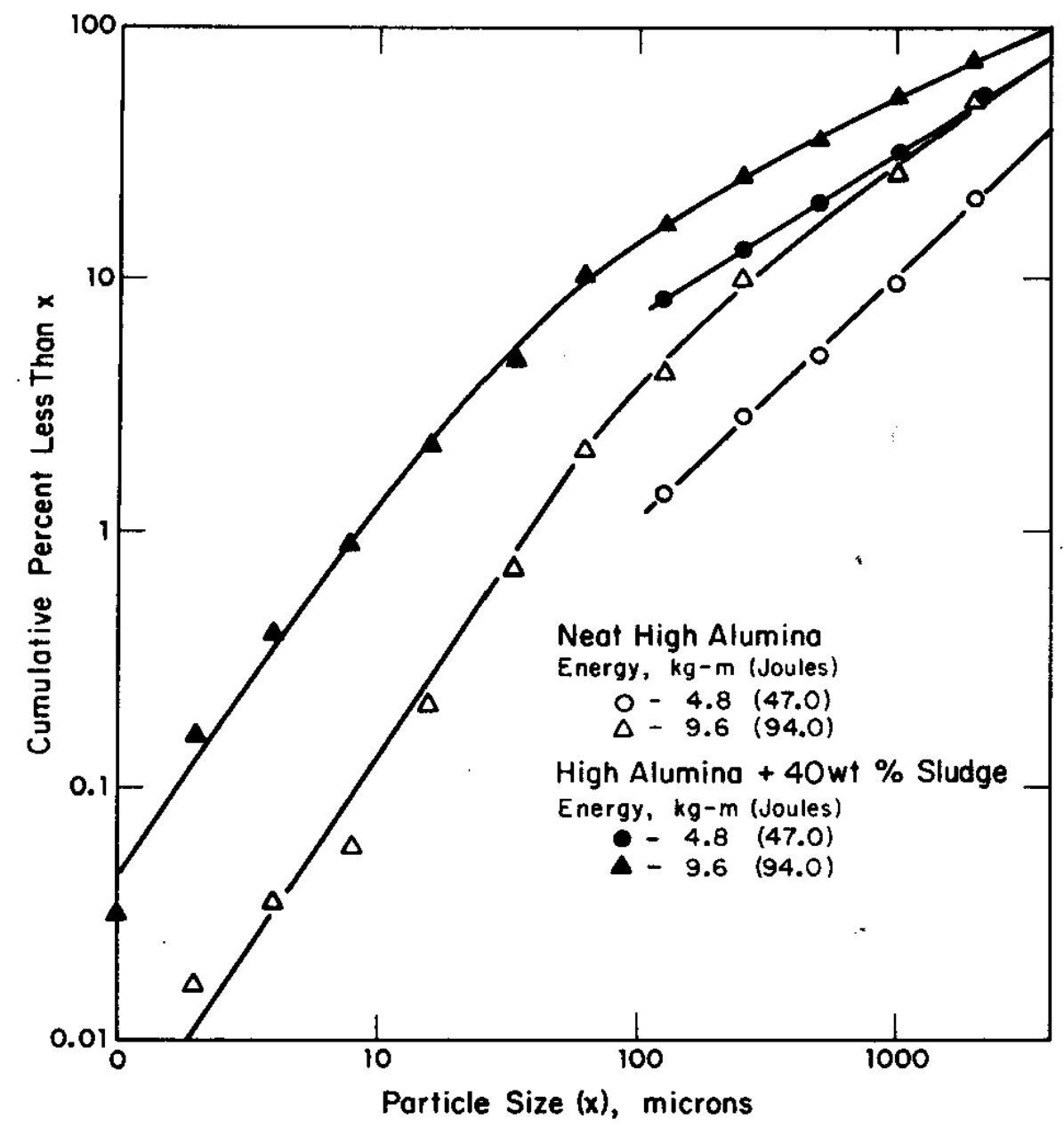

FIGURE 3. Particle Size Distribution of High Alumina Concrete Crushed by Impact 


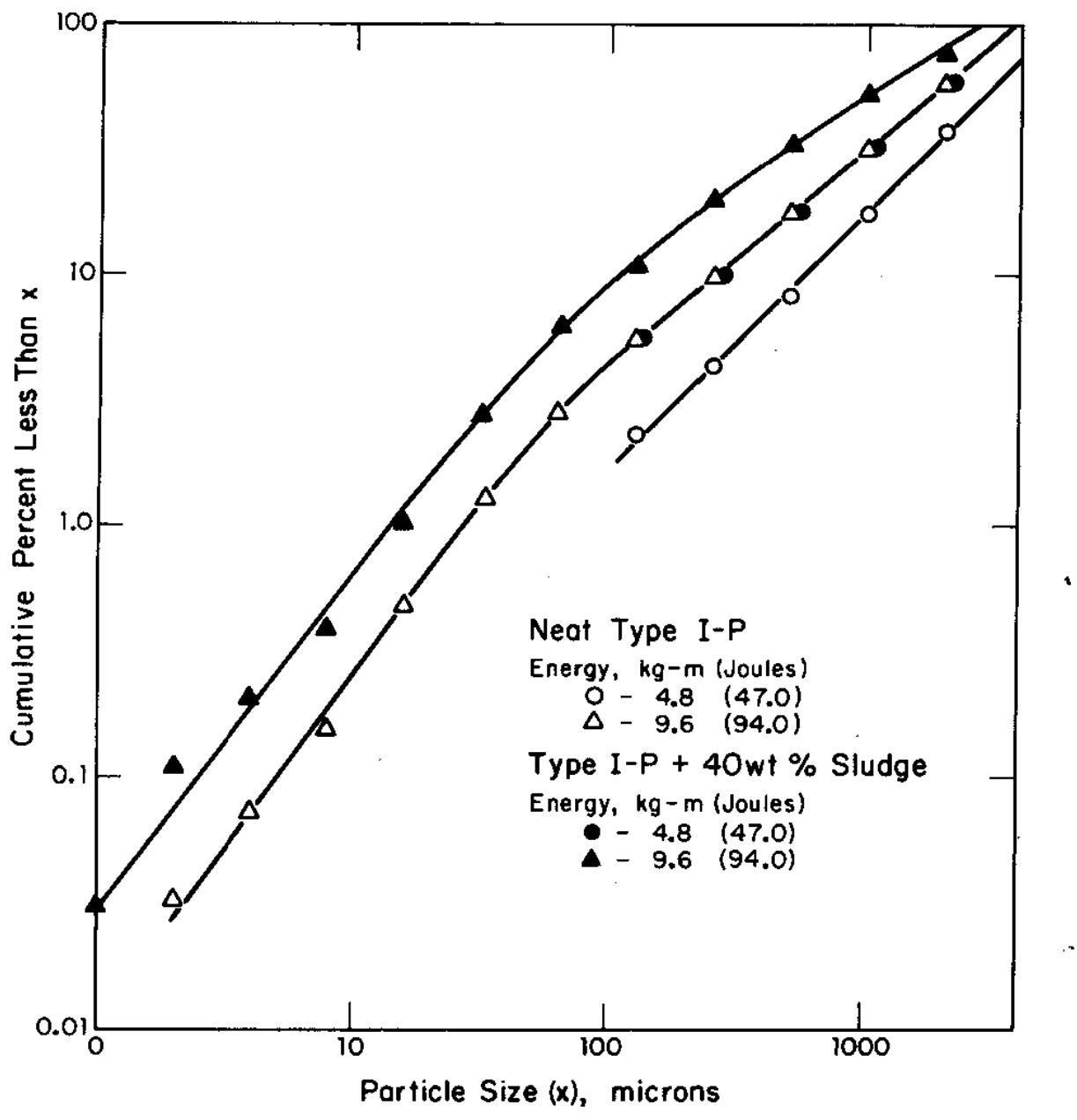

FIGURE 4. Particle Size Distribution of Type I-P Concrete Crushed by Impact 


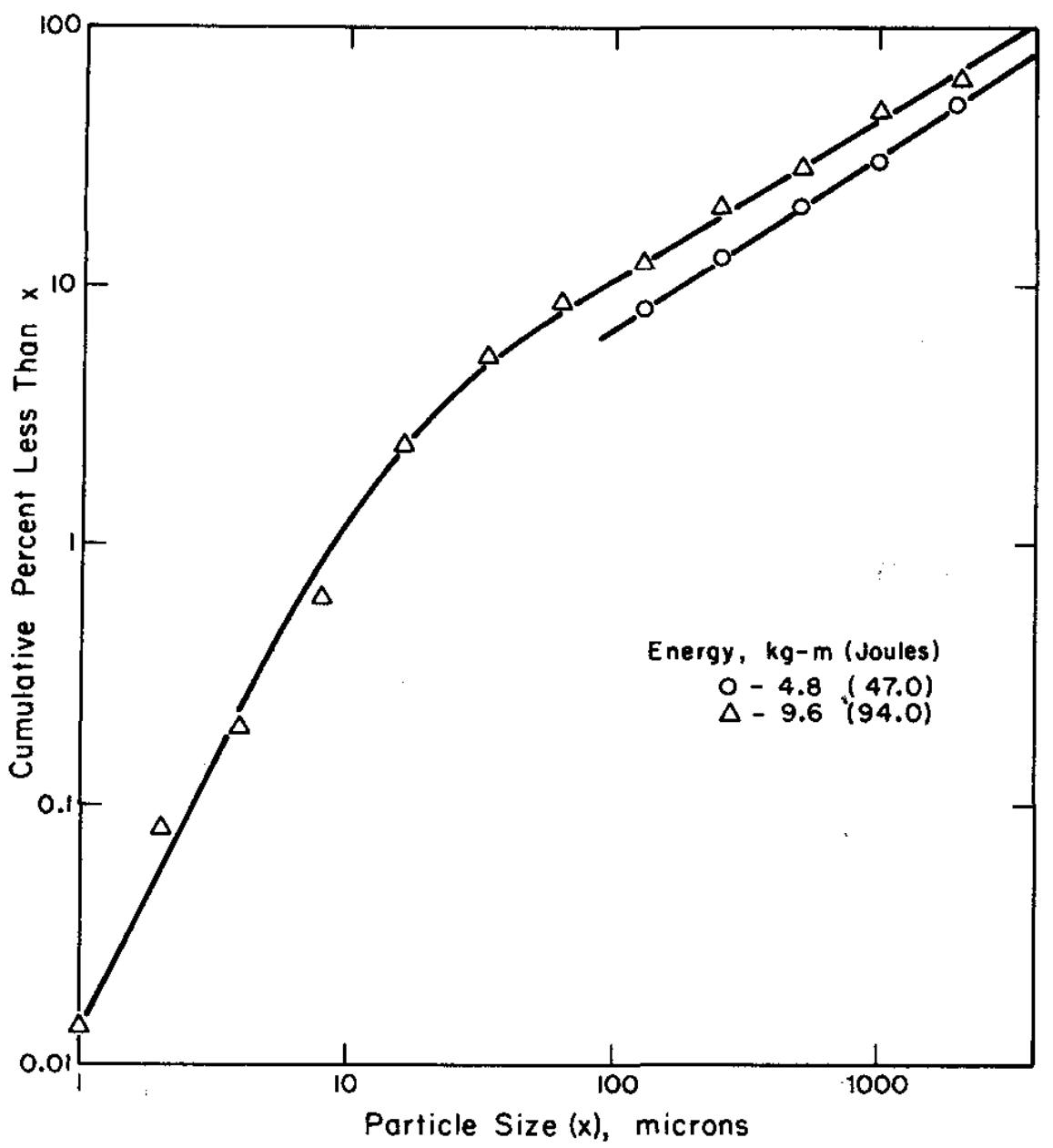

FIGURE 5. Particle Size Distribution of Type III Concrete Crushed by Impact

The fractions $f_{i}$, may be obtained from the tables by taking the differences between the cumulative percentages for two successive particle sizes and dividing by 100 . The average particle size, $\bar{x}_{i}$, is taken as the average of the maximum and minimum particle sizes within the fraction. The average particle sizes of the fractions in which the minimum particle size was 2000 microns were estimated by extrapolating the curves in Figures 2 through 5 back to a cumulative percent of 100 and taking the corresponding particle size as the maximum value within that fraction. 
It was possible to determine surface areas by the above procedure only for samples for which complete particle size distributions were obtained. Where only a limited particle size distribution was obtained, surface area was estimated by assuming that the surface area per gram of sample in the fraction of particle size less than 125 microns was identical to that in the same fraction of the same material for which a complete distribution was obtained.

Table 5 shows a summary of the surface areas of the crushed samples together with other data used in their calculations. Also shown are the energy input during crushing and the ratio of surface area to energy input, A/E. The surface areas shown are, of course, smaller than actual values because the assumption of spherical particles will lead to a minimum area. It may be possible to determine a roughness factor to correct for the difference between the surface areas of the actual particle and those calculated for spheres; however, the present results must be considered relative. The areas should also be corrected by subtracting the area of the original specimen because only the area generated by crushing is important to this work. These. corrections were not made, however, because of the uncertainties in the calculations just discussed; in any event the correction would be small (about $20 \mathrm{~cm}^{2}$ compared with the surface areas given in Table 5).

TABLE 5

Surface Area Created when Waste Forms were Crushed by Impact

\begin{tabular}{|c|c|c|c|c|c|c|}
\hline Scomple & $\begin{array}{c}\text { Mass }\left(g_{t}\right), \\
\text { groms }\end{array}$ & $\begin{array}{c}\text { Density ( } \rho), \\
g / m L\end{array}$ & $\begin{array}{c}\text { Energy }(E) \\
k g-m\end{array}$ & $\sum \frac{f_{i}}{x_{i}}, \mathrm{~cm}^{-1}$ & $\begin{array}{c}\text { Area (A), } \\
a \mathrm{~m}^{2}\end{array}$ & $\begin{array}{c}A \cdot E, \\
\mathrm{~cm}^{2} / \text { Joule }\end{array}$ \\
\hline Glass & 10.0 & 3.0 & 2.0 & 8.4 & 167 & 8.5 \\
\hline G1 ass & 10.0 & 3.0 & 4.0 & 19.3 & 385 & 9.8 \\
\hline Glass & 10.0 & 3.0 & 6.0 & 31.1 & 621 & 10.5 \\
\hline Glass & 10.0 & 3.0 & 8.0 & 37.1 & 742 & 9.5 \\
\hline $\begin{array}{l}\text { High Alumina, } \\
\text { Neat }\end{array}$ & $\begin{array}{l}12.6 \\
12.6\end{array}$ & $\begin{array}{l}2.15 \\
2.15\end{array}$ & $\begin{array}{l}4.8 \\
9.6\end{array}$ & $\begin{array}{r}7.5 \\
19.6\end{array}$ & $\begin{array}{l}264 \\
689\end{array}$ & $\begin{array}{l}5.6 \\
7.3\end{array}$ \\
\hline $\begin{array}{l}\text { Type I-P, } \\
\text { Neat }\end{array}$ & $\begin{array}{l}11.9 \\
11.9\end{array}$ & $\begin{array}{l}1.94 \\
1.94\end{array}$ & $\begin{array}{l}4.8 \\
9.6\end{array}$ & $\begin{array}{l}13.5 \\
26.4\end{array}$ & $\begin{array}{l}497 \\
972\end{array}$ & $\begin{array}{l}10.6 \\
10.3\end{array}$ \\
\hline $\begin{array}{c}\text { High Alumina }+ \\
40 \% \text { Sludge }\end{array}$ & $\begin{array}{l}11.2 \\
11.2\end{array}$ & $\begin{array}{l}1.97 \\
1.97\end{array}$ & $\begin{array}{l}4.8 \\
9.6\end{array}$ & $\begin{array}{l}29.5 \\
79.9\end{array}$ & $\begin{array}{l}1006 \\
2726\end{array}$ & $\begin{array}{l}21.3 \\
28.9\end{array}$ \\
\hline $\begin{aligned} \text { Type } & \text { I-P + } \\
40 \% & \text { Sludge }\end{aligned}$ & $\begin{array}{l}10.0 \\
10.0\end{array}$ & $\begin{array}{l}1.77 \\
1.77\end{array}$ & $\begin{array}{l}4.8 \\
9.6\end{array}$ & $\begin{array}{l}26.7 \\
53.9\end{array}$ & $\begin{array}{r}905 \\
1827\end{array}$ & $\begin{array}{l}19.2 \\
19.4\end{array}$ \\
\hline $\begin{array}{l}\text { Type III + } \\
40 \% \text { Sludge }\end{array}$ & $\begin{array}{l}9.1 \\
9.1\end{array}$ & $\begin{array}{l}1.57 \\
1.57\end{array}$ & $\begin{array}{l}4.8 \\
9.6\end{array}$ & $\begin{array}{l}46.2 \\
68.4\end{array}$ & $\begin{array}{l}1610 \\
2380\end{array}$ & $\begin{array}{l}34.2 \\
25.3\end{array}$ \\
\hline
\end{tabular}




\section{CONCLUSIONS}

The surface area divided by the energy input, $A / E$, in crushing (last column of $\mathrm{Table} 5$ ) was reasonably constant for each of the materials tested. This quantity might therefore be a useful parameter in defining the safety of solid waste forms. Values of $\mathrm{A} / \mathrm{E}$ were about the same for glass (average value $=9.6 \mathrm{~cm}^{2}$ / Joule) and for the samples of neat concrete studied, but were larger by factors of two to three for samples of concrete that contained $40 \mathrm{wt} \%$ sludge (average value $=24.7 \mathrm{~cm}^{2} / \mathrm{Joule}$ ).

Glass produced fewer fine particles that are likely to become airborne than did the specimens of concrete. In crushing with $8 \mathrm{~kg}-\mathrm{m}$ of energy per $10 \mathrm{gram}$ of sample, glass did not produce any particles that were less than 8 microns. Under only slightly more severe conditions $(9.6 \mathrm{~kg}-\mathrm{m}$ per $10 \mathrm{~g}), 0.016 \%$ to $0.032 \%$ of the neat concrete samples and $0.2 \%$ to $0.4 \%$ of the concrete samples containing sludge were converted to particles of less than 4 microns.

The preceding results indicate that impact testing can yield information concerning the increased potential of solid waste forms for leaching (increased surface area) and for creating an airborne hazard (production of fine particles) after being damaged in an accident.

\section{ACKNOWLEDGMENT}

The aid of the Nuclear Materials Division of the Savannah River Laboratory in determining detailed particle size analyses of crushed samples is gratefully acknowledged.

\section{REFERENCES}

1. J. A. Kelley. Evaluation of Glass as a Matrix for the Solidification of Savannah River Plant Waste - Nonradioactive and Tracer Studies. USERDA Report DP-1382, E. I. du Pont de Nemours \& Co., Savannah River Laboratory, Aiken, S. C. (1975).

2. J. A. Stone. Evaluation of Concrete as a Waste Solidification Matrix (to be published). 